\title{
Tonsillectomia versus tonsillotomia
}

\author{
Erdélyi Eszter dr. ${ }^{1}$ - Csorba Gréta dr. ${ }^{1}$ - Kiss-Fekete Beáta dr. ${ }^{1}$ \\ Fekete-Szabó Gabriella dr. ${ }^{1}$. Sztanó Balázs dr. ${ }^{1}$. Kiricsi Ágnes dr. ${ }^{1}$ \\ Zákány Zita dr. ${ }^{2}$ - Majoros Valéria $\mathrm{dr}^{2}{ }^{2}$ - Gaál Veronika $\mathrm{dr} .^{3}$ \\ Benedek Pálma dr. ${ }^{4}$ - Rovó László dr. ${ }^{1}$ - Bella Zsolt dr. ${ }^{1}$
}

\begin{abstract}
'Szegedi Tudományegyetem, Általános Orvostudományi Kar, Fül-Orr-Gégészeti és Fej-Nyaksebészeti Klinika, Szeged ${ }^{2}$ Szegedi Tudományegyetem, Általános Orvostudományi Kar, Aneszteziológiai és Intenzív Terápiás Intézet, Szeged ${ }^{3}$ Pécsi Tudományegyetem, Általános Orvostudományi Kar, Klinikai Központ, Gyermekgyógyászati Klinika, Pécs ${ }^{4}$ Heim Pál Országos Gyermekgyógyászati Intézet, Fül-Orr-Gégészeti Osztály, Budapest
\end{abstract}

\begin{abstract}
Bevezetés és célkitüzés: A szerző́k a posztoperatív fájdalom és a sebgyógyulás tekintetében prospektív vizsgálattal hasonlították össze gyermekeken (67 fó, 1-12 év) a hagyományos hidegeszközzel történő extracapsularis tonsillectomiát (23 fó) a microdebriderrel (23 fó) és a coblatorral (2l fó) végzett intracapsularis tonsillotomiával.

Módszer: A vizsgálatok a betegek által kitöltött kérdőívek, valamint prospektív klinikai adatgyújtés alapján történtek. Eredmények: Az intracapsularis tonsillotomia gyógyulási idejét 50\%-kal rövidebbnek találtuk, és az első 13 napban szignifikánsan kevesebb fájdalommal és fájdalomcsillapító igénnyel járt, mint az extracapsularis tonsillectomia eseteiben. A tonsillotomiás csoporton belül egyedül a posztoperatív első napi fájdalom tekintetében észleltünk szignifikáns különbséget a két különböző módszer között a coblator javára $(\mathrm{p}<0,05)$. A vizsgálatokat retrospektív áttekintéssel is kiegészítettük, 4 évi gyermek- (1-15 éves) tonsillamútéten átesett beteganyagunk (1487 fó) eredményeinek feldolgozásával. Tonsillectomia (1253 fó) után 7,7\%-os utóvérzési arányt észleltünk, mútéti vérzéscsillapításra 1,3\%-ban volt szükség. Tonsillotomia esetén (234 fó) 0,43\%-os utóvérzési arányt regisztráltunk. Ebben a csoportban vérzés miatt nem, de 2 esetben ismételt obstrukciót okozó hypertrophia, l esetben góctünetek miatt reoperációt végeztünk (1,28\%).

Következtetés: Eredményeiket a szerzők a nemzetközi ajánlások tükrében elemezték. Az intracapsularis tonsillotomia kisebb fájdalommal, kisebb vérzéssel és kisebb megterheléssel jár. A közösségbe való aktív visszatérés akár egy hét után lehetséges a tonsillectomiára jellemző 3 héttel szemben, mindez jelentős szocioökonómiai előnyökkel járhat. Orv Hetil. 2020; 161(45): 1920-1926.
\end{abstract}

Kulcsszavak: tonsillectomia, tonsillotomia, coblatio, microdebrider

\section{Tonsillectomy versus tonsillotomy}

Introduction and objective: Examining operated children in this prostective study inditerscompared (67 pts, 1-12 yrs) the extracapsular tonsillectomy with conventional cold-knife (23 pts) to extracapsular tonsillotomy with microdebrider (23 pts) and coblator (21 pts) for postoperative pain and wound-healing disorders.

Method: The study was based on patient-completed questionnaires as well as prospective clinical data collection.

Results: The recovery time of intracapsular tonsillotomy was found less than $50 \%$, with less pain than in the cases of extracapsular tonsillectomy. Postoperative pain was significantly less in the tonsillototomy group than the tonsillectomy group. Within the tonsillotomy group, a significant difference was observed between the two different methods in favor of the coblator for only the postoperative first-day pain. The studies were supplemented with a retrospective review by processing the 4 yrs results of their pediatric (1-15-yrs) patients who underwent tonsillectomy (1487 pts). After tonsillectomy (1253 pts), a postoperative bleeding rate of $7.7 \%$ was observed, and surgical hemostasis was required in $1.3 \%$. In the case of tonsillotomy ( $234 \mathrm{pts}$ ), a postoperative bleeding rate of $0.43 \%$ was recorded. In this group, reoperation was not performed due to bleeding, whereas it was neccesary in 2 cases due to hypertrophy causing repeated obstruction, in 1 case due by virtue of focal symptomes $(1.28 \%)$.

Conclusion: Our results were analyzed on the basis of international recommendations. Intracapsular tonsillotomy is associated with less pain, less bleeding, and less strain. Active return to the community is possible after up to a week compared to the 3 weeks typical of tonsillectomy, all of which can have significant socioeconomic benefits.

Keywords: tonsillectomy, tonsillotomy, coblatio, microdebrider 
Erdélyi E, Csorba G, Kiss-Fekete B, Fekete-Szabó G, Sztanó B, Kiricsi Á, Zákány Z, Majoros V, Gaál V, Benedek P, Rovó L, Bella Zs. [Tonsillectomy versus tonsillotomy]. Orv Hetil. 2020; 161(45): 1920-1926.

(Beérkezett: 2020. április 14.; elfogadva: 2020. május 22.)

\section{Rövidítések}

a. = arteria $\mathrm{CO}_{2}=$ szén-dioxid OSAS = (obstructive sleep apnea syndrome) obstruktív alvási apnoe szindróma; SRBD = (sleep-related breathing disorder) alváshoz kapcsolt légzési rendellenesség; SZTE = Szegedi Tudományegyetem; SZTE RKEB = SZTE Regionális Kutatásetikai Bizottság; SZTE SZAKK = SZTE Szent-Györgyi Albert Klinikai Központ

A tonsillectomia az egyik leggyakrabban végzett fül-orrgégészeti mútéti beavatkozás. Első leírója Celsus (Kr. e. 25-Kr. u. 50) [1]. A mütét technikája napjainkban is folyamatosan változik, finomodik az új vágó-koaguláló eszközök kifejlesztése kapcsán, valamint módosul a részleges és a teljes mandulaeltávolítás megítélése is. A tonsillectomia abszolút indikációi: szepszis, reumás láz, illetve peritonsillaris vagy parapharyngealis tályog. Az előbbiek száma a modern, széles spektrumú antibiotikumok mellett csökkenni látszik, míg az utóbbiak gyakorisága stagnál, illetve növekszik [2, 3]. Relatív indikációk a gyakori tonsillitisek (több mint 3-6 alkalom/év), a góctünetek, melyeket a tonsilla szöveti állományában retineálódott Streptococcus $\beta$-haemoliticus jelenlétének tulajdonítunk: foltos hajhullás, dermatitis, ízületi gyulladás, nephritis, pericarditis, myocarditis, iridocyclitis, krónikus prostatitis. Amennyiben a góctünetek gyakorisága és/ vagy súlyossága mellett a tonsillák gócszerepe bizonyíthatóvá válik, a haszon/kockázat gondos mérlegelése mellett a tonsillectomia indikációja abszolút mértékúvé válhat (például myocarditis, pericarditis, súlyos obstruktív állapotok). A tonsilla (tonsilla palatina) mint góc és a góctünetek közötti ok-okozati kapcsolat megállapítása jelenleg is szubjektív, elsősorban hosszú évtizedes klinikai tapasztalatok alapján történik, és ezek alapján szorgalmazzuk a teljes tonsillectomiát $[4,5]$. Az adenoid és a nyelvgyöki tonsillák, valamint a Waldeyer-garatgyürü egyéb járulékos nyirokelemei általában nem viselkednek gócként.

Megjegyzendő, hogy a nyugat-európai és az északamerikai országokban, és kiemelten az angolszász területeken, a tonsillectomia indikációja (Paradise-kritériumok) sokkal szigorúbb, és a tonsillectomiák incidenciája is jóval elmarad a hazai gyakorlattól. A tonsillotomia azaz a tonsilla palatina szöveti állományának részleges eltávolítása, megkisebbítése - indikációjának objektivizálására irányuló klinikai vizsgálatok jelenleg is zajlanak. Legfőképpen az alvásfüggő légzészavarok (SRBD) esetén, különösen annak obstruktív formájában (OSAS) alkalmazzák. A diagnosztikai „arany standardnak” tekin- tendő poliszomnográfia és a topodiagnosztikai megerősítés (például alvás alatti endoszkópia) alapján állítható fel a mütéti indikáció [6]. A horkolás sebészi terápiája kapcsán a garatplasztika mellett, annak kiegészítéseként vagy attól függetlenül, számos tankönyv ajánlja a tonsillectomiát vagy tonsillotomiát is. A Brodsky-féle tonsilla palatina stádiumbeosztás alapján a II-IV. stádium meghaladja a garatívek szintjét, a III-V. stádium pedig a tonsilla obstrukciót okozó szerepének alapos gyanúját veti fel (1. táblázat). A hypertrophiás vagy hyperplasiás tonsilla palatina tömegének megkisebbítése céljából partialis tonsillectomia, azaz tonsillotomia végzendő. A tonsillectomia teljes eltávolítást, míg a tonsillotomia bemetszést, megkisebbítést jelent. Az extracapsularis mútét során a tonsillatok és a paraphyaryngealis izomzat között vezetjük a metszést, azaz a tonsilla teljes szöveti állománya eltávolításra kerül (extracapsularis tonsillectomia). Intracapsularis tonsillectomia esetén a tonsilla teljes szöveti állományának eltávolítására törekszünk a tok megtartásával. Tonsillotomia során a tok mellett a szöveti állomány akár 70\%-a megőrizhető, minimális redukció a tonsillotomia során a garatívek szintjét meghaladó tonsillaállomány eltávolítása (2. táblázat) [7]. A tonsillotomia legfóbb előnye a posztoperatív fájdalom és vérzés radikális csökkenése, a csökkenő hospitalizáció és a közösségbe való visszatérés idejének felére csökkenése [8]. Hátránya a megmaradt tonsillaállomány hyperplasiája következtében ismételt obstrukció létrejötte, és gócbetegség esetén az inkomplett eltávolítás miatt megkérdőjelezhető a terápiás effektusa (a Streptococcus $\beta$-haemoliticus tartós jelenléte a megmaradt szöveti állományban). Ezért tonsillotomia azokban az esetekben végezhető, amelyekben a garatmandula túltengésén kívül a tonsillectomia indikációját képező eltérés, például igazolt gócbetegség nem áll fenn. Az elmúlt 20 év során az angolszász és a skandináv országokban a gyermekkori tonsillamütétek több mint $50 \%$-a partialis tonsillectomia (tonsillotomia) volt. Nem-

1. táblázat |A Brodsky-féle mandulastádiumok

\begin{tabular}{ll}
\hline Stádium & Jellemzók \\
\hline 1. stádium & $\begin{array}{l}\text { A tonsilla nagysága az elülső garatíveket nem haladja } \\
\text { meg. }\end{array}$ \\
2. stádium & $\begin{array}{l}\text { A tonsilla nagysága az uvula és az elülső garatív távolsá- } \\
\text { gának nem haladja meg a felét. }\end{array}$ \\
3. stádium & $\begin{array}{l}\text { A tonsilla nagysága az uvula és az elülső garatív távolsá- } \\
\text { gának felét haladja meg. }\end{array}$ \\
4. stádium & A középvonalban összeérnek a mandulák.
\end{tabular}


2. táblázat | Tonsillotomia versus tonsillectomia

\begin{tabular}{|c|c|c|c|c|c|}
\hline Módszer & Tok & $\begin{array}{l}\text { Eltávolított } \\
\text { tonsillaállomány }\end{array}$ & Intraoperatív vérzés & $\begin{array}{l}\text { Posztoperatív } \\
\text { vérzés }\end{array}$ & Posztoperatív fájdalom \\
\hline $\begin{array}{l}\text { Extracapsularis } \\
\text { tonsillectomia }\end{array}$ & $\begin{array}{l}\text { Eltávolításra kerül } \\
\text { (parapharyngealis izmok } \\
\text { szabaddá válnak) }\end{array}$ & $100 \%$ & $\begin{array}{l}\text { Jelentős, } \\
15-25 \mathrm{ml}\end{array}$ & $\begin{array}{l}\text { Jelentős } \\
\text { utóvérzési ráta, } \\
6-11 \%\end{array}$ & $\begin{array}{l}\text { Jelentős posztoperatív } \\
\text { fájdalom } 10-14 \text { napig }\end{array}$ \\
\hline $\begin{array}{l}\text { Intracapsularis } \\
\text { tonsillectomia }\end{array}$ & Megkímélt & $95-100 \%$ & $\begin{array}{l}\text { Kevesebb, } \\
10-15 \mathrm{ml}\end{array}$ & $\begin{array}{l}\text { Kevesebb } \\
\text { utóvérzés }\end{array}$ & $\begin{array}{l}\text { Kisebb posztoperatív } \\
\text { fájdalom }\end{array}$ \\
\hline $\begin{array}{l}\text { Intracapsularis } \\
\text { tonsillotomia }\end{array}$ & Megkímélt & $60-80 \%$ & $\begin{array}{l}\text { Minimális, } \\
5-10 \mathrm{ml}\end{array}$ & $\begin{array}{l}\text { Minimális } \\
\text { utóvérzési ráta }\end{array}$ & $\begin{array}{l}\text { Minimális fájdalom } 5-7 \text { napig, } \\
\text { van fájdalomcsillapító igény }\end{array}$ \\
\hline
\end{tabular}

zetközi tanulmányok szerint gyakori tonsillitisek esetében is jó eredménnyel és a panaszok szignifikáns csökkentésével végezhető a részleges mandulareszekció [9].

A mútéti eljárás technikai fejlődése a XIX. század második felétől vett új lendületet. Új sebészi eszközök kifejlesztésével, Ballenger (1906), Barne és Fowler (1930) hatására az extracapsularis tonsillectomia vált elfogadottá [10-12]. Ezen műtéteket hagyományos hidegtechnikával végezték. A több mint négy évtizede bevezetett bipoláris és monopoláris elektrokauter alkalmazása modernizálta a hagyományos eljárást, jelentős hőkárosodást okozó hatása miatt azonban a posztoperatív fájdalom csökkentésében nem jelentett előrelépést, így újabb eljárások kidolgozása kezdődött [13]. Az extracapsularis tonsillectomia napjainkban is $1-10 \%$ [14-16] utóvérzési kockázattal jár, ezen okok miatt például Ausztriában 5 éves kor alatt nem végeznek rutinszerűen tonsillectomiás beavatkozást [17]. Saját korábbi protokollunk 3 éves kor alatt nem, 6 éves kor alatt korlátozott indikációval engedélyezte a tonsillectomia elvégzését, amit azonban számtalan esetben felülírtak.

Az új eszközök megjelenésével újabb térhódítást nyert a garatmandulák részleges eltávolítása, főleg azon esetekben, amelyekben a hipertrofizált tonsilla palatinák garatot jelentősen szúkítő hatása áll előtérben a gyakori mandulagyulladásokkal szemben. A partialis tonsillaeltávolításhoz számos új eszközt alkalmazhatunk, mint például ultrahangos szike, coblator, rádiófrekvenciás vágóeszköz, $\mathrm{CO}_{2}$-lézer, microdebrider (shaver). Ezen új eszközök használatával, valamint azzal, hogy a tonsillaállományt részlegesen megkíméljük - így nem sértjük a parapharyngealis izmokat -, jelentősen lecsökkent a perioperatív fájdalom és a posztoperatív vérzés előfordulása [8, 10, 18]. Koltai és mtsai 2002-ben számoltak be első alkalommal microdebriderrel szerzett pozitív tapasztalataikról [19], majd 2005-ben Chang és mtsai írtak coblatorral szerzett még kedvezőbb eredményeikről [20]. Klinikánkon a korábbiakban összehasonlító vizsgálatot végeztünk az intracapsularis partialis (tonsillotomia), valamint az extracapsularis teljes (tonsillectomia) mandulaeltávolítás tekintetében, amelynek alapján a nemzetközi eredményekhez hasonlóan a részleges mandulareszekció szignifikánsan kisebb posztoperatív fájdalommal járt. A Heim Pál Gyermekkórház vizsgálatai során hasonló eredményeket kaptak [21].

Az SZTE SZAKK Fül-Orr-Gégészeti és Fej-Nyaksebészeti Klinikáján végzett vizsgálatokkal a tonsillectomia és a tonsillotomia perioperatív és hosszú távú hatásait kívántuk összehasonlítani. Az etikai engedély: SZTE RKEB. Iktatószám: 203/2013.

I. Prospektív vizsgálatot végeztünk a hagyományos extracapsularis tonsillectomia (hidegeszköz) és az intracapsularis tonsillotomia (shaver és coblatio) összehasonlítására a posztoperatív fájdalom és a sebgyógyulás tekintetében, saját, 1-12 év közötti gyermekbeteganyagban.

II. Retrospektíven áttekintettük 4 év beteganyagában a klinikán 1-15 év közötti gyermekeken végzett tonsillectomiák és tonsillotomiák mútéti eredményeit a korai és késői szövődmények megítélésére.

\section{Módszer}

I. A prospektív vizsgálathoz a klinikánkra előjegyzett betegek közül önkéntes alapon választottuk ki a résztvevőket. A betegtájékoztatót az SZTE Humánetikai Bizottságának kérésére rajzos illusztrációval a gyermekek számára is érthetővé tettük.

1. csoport. Extracapsularis tonsillectomia: a hagyományos hidegtechnika esetében a már jól ismert Cooperollót, raspát és bipoláris csipeszt, valamint szükség esetén lekötéseket alkalmazunk.

2. csoport. Intracapsularis tonsillotomia microdebrider (shaver) használatával. Ez egy apró, forgó pengével ellátott eszköz, amely múködése közben a pengével levágott szövetdarabokat egy szívórendszerrel azonnal elszívja a mútéti területről. A vérzéscsillapítás, koagulálás nagyfrekvenciás bipoláris csipesszel történt.

3. csoport. Intracapsularis tonsillotomia coblatorral (plazmakés): a coblator külön vágóéllel nem rendelkező eszköz, a kézi darab nátriumtartalmú fémszálakat tartalmazó végén ionokban gazdag folyadékközegben (fiziológiás só) plazmaréteg keletkezik, amely a szöveteket kémiai ablatióval szétválasztja, és a beépített szívó a folyadékot, vért, szövetdarabokat azonnal elszívja. Az eszköz alacsony hőfok mellett rádiófrekvenciás koagulálással vérzéscsillapításra is képes (2. és 3. táblázat). 
3. táblázat |Az alkalmazott eszközök és hőterhelésük

\begin{tabular}{lll}
\hline Eszköz & Múködési elv & Termelt hő \\
\hline Hidegeszköz & $\begin{array}{l}\text { Vágás éllel rendelkező } \\
\text { eszközzel }\end{array}$ & $\begin{array}{l}\text { Vérzéscsillapításhoz } \\
\text { használt bipoláris } \\
\text { eszközzel }\end{array}$ \\
\hline Coblator & $\begin{array}{l}\text { Plazmaképzés (ablatio), } \\
\text { rádiófrekvencia } \\
\text { (coagulatio), folyamatos } \\
\text { szívás }\end{array}$ & $\begin{array}{l}\text { Abláló funkció } 40{ }^{\circ} \mathrm{C}, 70{ }^{\circ} \mathrm{C} \\
\text { coaguláló funkció }\end{array}$ \\
\hline $\begin{array}{l}\text { Microdebrider } \\
\text { (3000-es }\end{array}$ & $\begin{array}{l}\text { Mechanikus, folyamatos } \\
\text { szívás }\end{array}$ & Nincs hőtermelés \\
$\begin{array}{l}\text { Medtronic IPC/ } \\
\text { Shaver }\end{array}$ & & \\
\hline
\end{tabular}

A mútétek során SN 71871 microdebridert (Medtronic, Dublin, Írország) és Coblator II 13546-02 coblatort (ArthroCare, Austin, TX, Egyesült Államok) használtunk. A mandula részleges megkisebbítését protokollszerúen, legalább a garatívek szintjéig végezzük. Az alsó pólusban a garatívek szintjén túl is redukáljuk a tonsillaállományt, mivel ez a legszúkebb terület, és tapasztalataink szerint a megnagyobbodott tonsilla általában itt okozza a legjelentôsebb szúkületet.

A prospektív vizsgálat során a peri- és posztoperatív időszakban kérdőíves módszerrel összesen 67, 1-12 év közötti gyermeket követtünk (az átlagéletkor tonsillectomia esetében 4,95 $\pm 1,36$ év, coblatoros tonsillotomia esetében 4,47 $\pm 2,17$ év, míg shaveres tonsillotomia esetében $3,89 \pm 1,28$ év volt). Hidegeszközzel, majd bipoláris koagulációval hagyományos tonsillectomiát 23 esetben, shaveres tonsillotomiát 23, míg coblatiós tonsillotomiát 21 betegen végeztünk. A csoportokat mútét előtt, a beavatkozás alapjául szolgáló diagnózis szerint alakítottuk ki. Tonsillotomiát kizárólag az OSAS indikációjánál alkalmaztunk, ezen belül $1: 1$ arányú randomizációval hoztuk létre a két alcsoportot (shaver, illetve coblator). Az OSAS diagnózisának megállapítása szülói megfigyelések, video- és hangfelvételek, 4 év felett kétes esetekben poligráfia alapján történik. Topodiagnózis céljából a mútét bevezető fázisában még az intubáció előtt spontán légzés mellett alvási endoszkópia végezhető. Súlyos OSAS-beteg a jelen vizsgálatba nem került bevonásra. A vizsgálatot befolyásoló szív-ér rendszeri, hematológiai, hormonális, súlyos fokú légzőszervi és bármely pszichiátriai betegség kizáró tényező volt. A mútétet minden esetben általános érzéstelenítésben, endotrachealis intubációval végeztük. Premedikációként a gyermekek testtömegtől függően per rectum Dormicumot (midazolám) kaptak maximum fél órával a beavatkozás előtt. A mútét során a fájdalomcsillapítás céljából intravénásan Nubaint (nalbufin-hidroklorid), illetve per rectum Mexalen (paracetamol) kúpot alkalmaztunk. A posztoperatív fájdalomcsillapítást a gyermekek benntartózkodása alatt per os diklofenákcseppel végeztük. A gyermekek között diklofenákérzékenység nem volt.

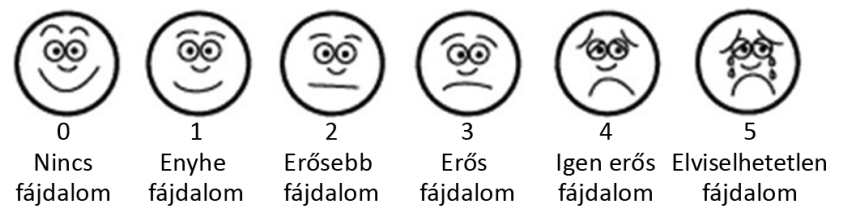

1. ábra | A Wong-Baker-fájdalomskála

A beavatkozás után 3 hétig tartó kérdő́ives utánkövetést végeztünk, valamint a gyermekeket minimum egy alkalommal kontrollvizsgálatra rendeltük vissza. A szülők által vezetett posztoperatív kérdőív az alábbi szempontokat tartalmazta: a fájdalom mértéke (naponta $3 \times$, a gyermek és a szülő által is értékelve $0-5$-ös skálán), a fájdalomcsillapító mennyisége (csepp/nap), folyadékbevitel (a szüló regisztrálta $\mathrm{dl} /$ nap egységben), testsúly (naponta mérve, tizedes pontossággal, kg-ban megadva), az étkezések száma és mennyisége (a szülő rögzítette az étkezések számát, és a gyermek normál étkezési mennyiségtől való eltérését), valamint az általános állapot értékelése.

Szövődmény esetén is intézetünkben láttuk el a betegeket, így az összes posztoperatív komplikációról értesültünk. Az adatgyújitések során feljegyeztük a mútét hosszát és a posztoperatív fájdalmat, valamint a posztoperatív szövődményeket. Az eredményeket 2 mintás T-próbával értékeltük, a csoportokat páronként hasonlítottuk össze $(\mathrm{p}<0,005)$.

A fájdalom értékelésére a 6 fokozatú $(0-5)$ Wong-Baker-féle rajzos fájdalomskálát használtuk (1. ábra).

\section{Eredmények}

\section{Prospektín vizsgálat}

A különböző eszközökkel végzett beavatkozások mútéti ideje között a tanulási időszakot követően nem észleltünk különbséget. Prospektív, utánkövetéses, kérdőíves vizsgálatunkban a posztoperatív időszakban az általános állapotban, a táplálhatóságban (az étkezések száma és mennyisége), a fogyasztott folyadék mennyiségében, a testtömegváltozásban a csoportok között különbség nem volt észlelhetó, egyik csoportban sem volt átlagosan több mint 5\%-os testtömegcsökkenés, illetve -gyarapodás. 1 esetben tonsillectomián átesett gyermeknél többszöri hányás mellett észleltünk 10\%-os súlycsökkenést, 3 esetben ( 1 coblatiós és 2 shaveres tonsillotomia) pedig $5 \%$ feletti testsúlygyarapodást detektáltunk. Az extracapsularis tonsillectomiával szemben, korábbi eredményeinkkel megegyezően, mindkét módszerrel végzett tonsillotomia az elsô 13 napban szignifikánsan kisebb fájdalommal $(\mathrm{p}<0,05)$ és fájdalomcsillapító-igénnyel járt. A tonsillotomiát követố fájdalom a 7 . nap végére csaknem teljesen lecsengett (a fájdalomcsillapító-igény kevesebb mint $0,5 \mathrm{csepp} / \mathrm{kg} /$ nap volt), míg tonsillectomia után átlagosan 14 napig fennállt. A coblatióval végzett tonsillotomia esetében az első 7 napban tendenciajellegúen kisebb volt a fájdalomcsillapító-igény, mint a mic- 

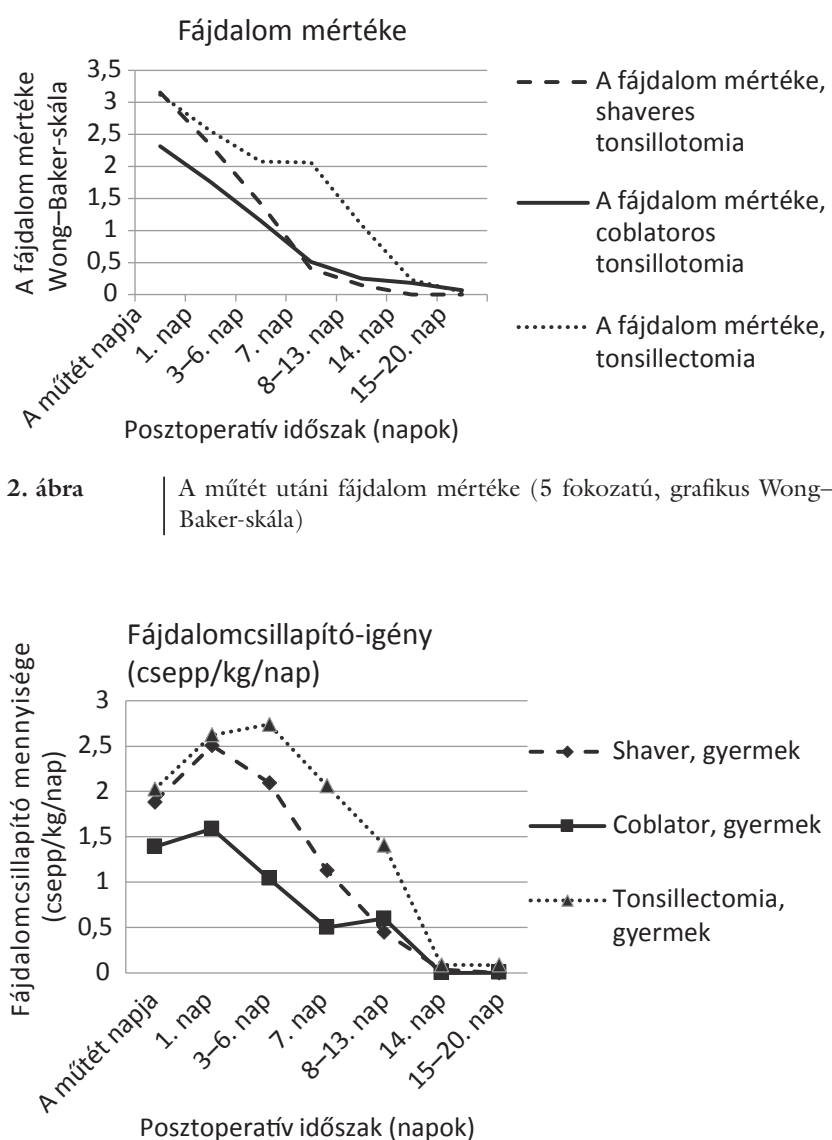

3. ábra $\mid$ Mútét utáni napi fájdalomcsillapító (diklofenák)-igény (a testtömegkilogrammra vonatkoztatott cseppek száma alapján)

rodebrideres tonsillotomia után, a különbség azonban csak az első nap esetében volt szignifikáns $(\mathrm{p}<0,05)$. A fájdalomcsillapító-igény csökkenése csak néhány nappal a fájdalom csökkenése után jelentkezik. A kérdőívek 'megjegyzés' rovatába többször bekerült, szülői megjegyzésként: „Miután napok óta nem volt fájdalom, mertük csak a fájdalomcsillapító mennyiségét csökkenteni, majd végül elhagyni” (2.és 3. ábra) [22].

\section{Retrospektív vizsgálat}

A különböző tonsilla palatina műtéti típusok hosszú távú mútéti eredményeinek összehasonlíthatósága érdekében klinikánk beteganyagát retrospektív módon is áttekintettük. A vizsgált 4 évben (2014. 01. 01.-2017. 12.31.) az SZTE Fül-Orr-Gégészeti és Fej-Nyaksebészeti Klinikáján 1487 tonsillamútét (1253 teljes mandulaeltávolítás, 234 mandulamegkisebbítés) történt az 1-15 éves korosztályban. Az elvégzett 1253 gyermektonsillectomia során 95, késői típusú (posztoperatív 5-10. nap közötti) utóvérzést észleltünk $(7,7 \%)$, ebből 17 szorult ismételt beavatkozásra $(1,4 \%)$, a többi 78 esetben elegendő volt 24 órás intézeti obszerváció $(6,3 \%)$. Intézetünkben az ugyanezen időszak alatt végzett 234 tonsillotomia közül 1 esetben $(0,43 \%)$ észleltünk utóvérzést, de a gyermeknek a klinikára történő beérkezésekor vérzés már nem volt tapasztalható. Egyéb posztoperatív szövődmények miatt tonsillectomia után összesen 15 esetben történt ismételt osztályos felvétel, valamint 1 esetben tonsillotomia után. A felvételre 10 esetben kiszáradás és táplálási nehezítettség, 4 esetben magas láz és l esetben peritonsillitis miatt került sor. Parenteralis folyadékpótlás és antibiotikum mellett a betegek néhány napon belül gyógyultak. Tonsillotomia esetén mindössze $\mathrm{l}$ beteget hospitalizáltunk lázas állapot miatt.

A tonsillotomián átesett gyermekek esetében reoperációra, komplettáló tonsillectomiára, illetve ismételt tonsillaállomány-megkisebbítésre 234-ból 3 esetben volt szükség (1,28\%). Az elsô esetben l évvel késóbb, korábban nem észlelt bőrgyógyászati panaszok miatt, a második esetben gyakori tonsillitisek és ismételt obstrukciót okozó hypertrophiás tonsillák miatt komplettáló tonsillectomiát végeztünk. A harmadik esetben újból obstrukciót okozó hypertrophiás tonsillák miatt ismételt tonsillotomia mellett döntöttünk (a gyermek anamnézisében akut tonsillitisek, illetve góctünetek nem szerepeltek). Mindhárom esetben, amelyeknél ismételt beavatkozást kellett végrehajtani, az elsó alkalommal microdebriderrel történt a tonsillotomia. A reoperációk során 2 esetben tonsillectomiát és 1 esetben coblatoros tonsillotomiát végeztünk.

\section{Megbeszélés}

A hagyományos indikáció (gyakori tonsillitisek és gócbetegség) esetén a tonsilla palatina szöveteinek tok mentén történő teljes eltávolítása, (extracapsularis) tonsillectomia, míg OSAS esetén intracapsularis tonsillotomia (partialis tonsillectomia) javasolt; technikai kivitelezésük speciális eszközöket igényel [23]. Tonsillotomia, azaz a tonsilla palatina szöveti állományának redukciója számos eszközzel (shaver, rádiófrekvenciás vagy nagyfrekvenciás vágóeszköz, coblatio) könnyedén kivitelezhető.

Vizsgálati eredményeink alapján az intracapsularis tonsillotomia szignifikánsan kisebb posztoperatív fájdalommal, kisebb mútéti megterheléssel és kisebb szövődményrátával jár, mint a hagyományos extracapsularis tonsillectomia, ahogyan azt eddig a nemzetközi irodalomban és saját korábbi vizsgálatunk alapján is láthattuk $[1,10,18-20]$. A tonsillatok megórzésével a parapharyngealis izomzat és az idegvégződések és nagyobb erek fedetten maradnak. A mandulatok mint intakt barrierfelszín a gyorsabb áthámosodást is elősegíti. Kisebb a posztoperatív fájdalom, és csökken az utóvérzés lehetô" sége, gyorsabb a sebgyógyulás. A tonsillotomia esetében a két technika közötti fájdalombeli különbség a coblatiós eszköz és a bipoláris csipesz hőtermelésbeli különbségének és az így okozott eltérő járulékos szövetkárosodásnak köszönhető [8]. Ezen feltételezésünk bizonyítása további vizsgálatokat igényel.

Retrospektív elemzéseink alapján a posztoperatív vérzés tekintetében - a nemzetközi eredményekkel megegyezően - intézetünkben tonsillotomia esetén több 
mint 7\%-kal kisebb volt a vérzési ráta a tonsillectomiához hasonlítva $[23,24]$. A posztoperatív vérzés tonsillectomia után $7,7 \%$ volt, ami megfelel a nemzetközi gyakorlatnak, míg tonsillotomia után a vérzés mindössze $0,43 \%$ volt. Utóvérzést tonsillotomia után 1 esetben észleltünk, mely beavatkozást nem igényelt. A tonsillotomiát ebben az esetben adenotomiával egybekötve microdebriderrel végeztük. A shaver használata esetén különösen ügyelnünk kell a garatívek és a nyelvcsap sérülésének megelőzésére. A coblatorral végzett beavatkozások esetében posztoperatív vérzést nem tapasztaltunk. Az utóvérzés miatt ismételt osztályos felvételre kerülő gyermekek nagy részében a beérkezéskor már sem aktív vérzés, sem koagulum nem látható. Így viszonylag magas utóvérzési ráta mellett is alacsony a beavatkozást igénylő vérzések száma $[16,25,26]$. A posztoperatív vérzést azonban igen nehéz identifikálni, illetve nagyon széles skálán mozog a mértéke. A legveszélyesebb az a. lingualis területéről észlelt vérzés, amely beavatkozást igényel. Az alsó pólusból észlelt, különösen az intermittáló jellegű vérzés felveti az a. lingualis sérülésének lehetőségét, ismétlődő vagy profúz vérzés esetén az alsó pólus aláöltése válhat szükségessé. Az a. pharyngea descendens és ascendens területéről induló vérzések általában ritkábban fordulnak elő, ezek többnyire elektrokoagulációval elláthatók. A vérzések és a felvételt igénylő kiszáradás (dehidráció) és láz hátterében azonban a legtöbb esetben a rosszul felmért és csillapított fájdalom és a nem megfelelő hidratáltság áll. Rendkívül fontos, hogy ezek veszélyére a szülők, gondviselők figyelmét felhívjuk, valamint intézeti protokolljainkat e szerint alakítsuk ki, illetve alakítsuk át [25, 27,28 ]. Tonsillotomia után az ismételt mútéti indikációt jelentő panaszok (hypertrophia, OSAS, gyakori tonsillitis, gócpanasz) igen különböző előfordulási gyakoriságot mutatnak, intézetünkben a vizsgált 4 évben igen alacsony százalékban (teljes klinikai beteganyagunkban: $3 / 234$ [1,28\%]) észleltünk ilyen pácienseket. Mindhárom esetben a tonsillotomiás metódus bevezetésének kezdeti fázisában végeztük a primer beavatkozást, amikor még kevesebb volt a tapasztalatunk azzal kapcsolatban, hogy milyen mértékü állománymegkisebbítést szükséges végeznünk. Tonsillotomia esetében nehéz meghatározni az eltávolítandó szövet mennyiségét, tapasztalataink azonban azt mutatják, hogy legalább a garatívekig kell eltávolítani a szöveteket, valamint az alsó pólusban a garatíveket meghaladóan is, ezzel homorú felszínt kell kialakítani, számolva a nyirokszövet hypertrophiás és hyperplasiás habitusára. 1-6 éves populációban adenotomiát követően a Waldeyer-garatgyürü területén következményes lymphaticus hypertrophia, hyperplasia jelentkezik. A preoperatív II-IV. stádiumú, egyébként tünetmentes tonsillák a mütét után néhány hónappal hypertrophiát mutatnak, gyakran alvási apnoét okoznak. Ezen betegcsoportban a primer adenotomia kapcsán egyidejúleg tonsillotomia (a szöveti állomány megkisebbítése, grade II-IV. esetén) szintén meggondolandó. A visszatérő panaszok nagymértékben függenek a mútéti technikától, az operatőr jártasságától, és nem feltétlenül a partialis tonsillectomia létjogosultságát kérdőjelezik meg $[7,19,23]$.

A tonsillotomia aránya intézetünkben a bevezetést követő években 18-19\%-ra emelkedett, de még nem éri el a nyugat-európai és észak-amerikai gyakoriságot (80\%). A nemzetközi gyakorlatban tonsillotomiát már gyakori tonsillitisek esetében is végeznek $[8,29]$.

\section{Következtetés}

A hagyományos hazai fül-orr-gégészeti iskola tapasztalati okokból mind a gyakori tonsillitisek, mind a feltételezett tonsillogen szövődmények esetén a teljes tonsillaszövet eltávolítását, azaz tonsillectomiát tartott szükségesnek. Obstruktív alvási apnoe esetén a teljes tonsillaszöveti állomány eltávolítása bizonyosan felesleges. Megfelelő indikáció mellett a tonsillectomia helyett tonsillotomia elegendő lehet. A tonsillotomia utáni kisebb fájdalom és minimális utóvérzési kockázat, valamint az átlagosan 50\%-kal rövidebb gyógyulási időtartam alapján a gyermekek akár egy hét után (szemben a jelenlegi három héttel) visszatérhetnek a közösségbe; mindez jelentős szocioökonómiai előnyökkel jár.

A fenti megfigyelések további klinikai vizsgálata és az új mútéti metódusok és eszközök kipróbálása, saját tapasztalatok szerzése alapvető klinikusi feladat. Az új eszközök és technikák bevezetése segítheti a fejlődést. A napi gyakorlatba való bevezetésük, biztonságos és hatékony használatuk 'skill' képzéssel és kadávergyakorlatok keretein belül elsajátíthatók. A technikai fejlődés nyújtotta előnyök, amelyek egyes múszerekhez köthetők, eltörpülnek a tonsillotomia versus tonsillectomia indikációs kérdéshez képest. Nem a technika, hanem a helyes indikáció határozza meg a mútét eredményességét.

Anyagi támogatás: A jelen közlemény megírása és az adatgyüjtés során anyagi támogatásban egy szerző sem részesült.

Szerzői munkamegosztás: E. E.: Adatgyüjtés, kapcsolattartás a betegekkel és a szülőkkel, a kérdőívek összesítése, a közlemény megírása. Cs. G.: Adatgyưjtés, a kérdőívek összesítése. Sz. B., K.-F. B., F.-Sz. G., K. Á.: A tanulmányunkban szereplő betegek koordinálása. Z. Z., M. V.: R. L.: Tudományos szupervizor. B. Zs.: A tanulmány vezetője.

Érdekeltségek: A szerzőknek nincsenek érdekeltségeik.

\section{Irodalom}

[1] Bach Á, Bella Zs, Sztanó B, et al. Microdebrider performed intracapsular tonsillotomy versus traditional tonsillectomy in point of postoperative pain and postoperative healing period. [A microdebriderrel végzett intracapsularis shaver tonsillectomia és a hagyományos extracapsularis tonsillectomia összehasonlítása a 
posztoperatív fájdalom és a sebgyógyulás tekintetében.] Otorhinolaryngol Hung. 2014; 60: 54-57. [Hungarian]

[2] Répássy G. Indication of tonsillectomy. In: Répássy G. (ed.) Earnose-throat and head-neck surgery. [A tonsillectomia indikációja. In: Répássy G. (szerk.) Fül-orr-gégészet, fej-nyak-sebészet.] Medicina Könyvkiadó, Budapest, 2011; pp. 327-328. [Hungarian]

[3] Lepelletier D, Pinaud V, Le Conte P, et al. Is there an association between prior anti-inflammatory drug exposure and occurrence of peritonsillar abscess (PTA)? A national multicenter prospective observational case-control study. Eur J Clin Microbiol Infects Dis. 2017; 36: 57-63.

[4] Pentecost RS. Focal infection in the tonsils of adults suffering from sub-acute and chronic systemic disease: analysis of results of removal in a series of 800 cases. Can Med Assoc J. 1922; 12: 886-891.

[5] Randel A. AAO-HNS Guidelines for tonsillectomy in children and adolescents. Am Fam Physician 2011; 84: 566-573.

[6] Benedek P, Katona G. The role of sleep endoscopy in the diagnosis of pediatric obstructive sleep apnea syndrome. [A sleep endoscopia helye a gyermekkori obstruktív alvási apnoe szindróma diagnosztikájában.] Otorhinolaryngol Hung. 2011; 57: 84-88. [Hungarian]

[7] Hultcrantz E, Ericsson E. Factors influencing the indication for tonsillectomy: a historical overview and current concepts. ORL J Otorhinolaryngol Relat Spec. 2013; 75: 184-191.

[8] Somogyvári K, Móricz P, Szanyi I, et al. Tonsillectomy versus RF tonsillotomy in childhood (pilot study). [Tonsillectomia versus rádiófrekvenciás tonsillotomia gyermekkorban (pilot study).] Otorhinolaryngol Hung. 2014; 60: 155-160. [Hungarian]

[9] Windfuhr JP. Indications for tonsillectomy stratified by the level of evidence. GMS Curr Top Otorhinolaryngol Head Neck Surg. 2016; 15: Doc09.

[10] Mixson CM, Weinberger PM, Austin MB. Comparison of microdebrider subcapsular tonsillectomy to harmonic scalpel and electrocautery total tonsillectomy. Am J Otolaryngol. 2007; 28: $13-17$.

[11] Fowler RH. Tonsil surgery. W. B. Davis Company, Philadelphia, PA, 1930

[12] Koempel JA. On the origin of tonsillectomy and the dissection medhod. Laryngoscope 2002; 112: 1583-1586.

[13] Du W, Ma B, Guo Y, et al. Microdebrider vs. electrocautery for tonsillectomy: a meta-analysis. Int J Pediatr Otorhinolaryngol. 2010; 74: 1379-1383.

[14] Peterson J, Losek JD. Post-tonsillectomy hemorrhage and pediatric emergency care. Clin Pediatr (Phila). 2004; 43: 445-448.

[15] Harounian JA, Schaefer E, Schubart J, et al. Pediatric adenotonsillectomy and postoperative hemorrhage: demographic and geographic variation in the US. Int J Pediatr Otorhinolaryngol. 2016; 87: 50-54.

[16] Sarny S, Ossimitz G, Habermann W, et al. Hemorrhage following tonsill surgery: a multicenter prospective study. Laryngoscope 2011; 121: 2553-2560.
[17] Kindlinger N. Impact des Konsensuspapiers 2007 zur Tonsillektomie. Erstellt am Fachhochschul-Studiengang, Prozessmanagement Gesundheit, FH OÖ, Standort Steyr. Steyr, 2012. Available from: https://docplayer.org/36216339-Impact-des-konsensuspapiers-2007-zur-tonsillektomie.html [accessed: May 20, 2020].

[18] Wilson YL, Merer DM, Moscatello AL. Comparison of three common tonsillectomy techniques: a prospective randomized, double-blinded clinical study. Laryngoscope 2009; 119: 162170.

[19] Koltai PJ, Solares CA, Mascha EJ, et al. Intracapsular partial tonsillectomy for tonsillar hypertrophy in children. Laryngoscope 2002; 112(Suppl 100): 17-19.

[20] Chang KW. Randomized controlled trial of coblation versus electrocautery tonsillectomy. Otolaryngol Head Neck Surg. 2005; 132: 273-280.

[21] Deak L, Saxton D, Johnston K, et al. Comparison of postoperative pain in children with two intracapsular tonsillotomy techniques and a standard tonsillectomy: microdebrider and radiofrequency tonsillotomies versus standard tonsillectomies. Sultan Qaboos Univ Med J. 2014; 14: e500-e505.

[22] Sirintawat N, Sawang K, Chaiyasamut T, et al. Pain measurement in oral and maxillofacial surgery. J Dent Anesth Pain Med. 2017; 17: $253-263$

[23] Hultcrantz E, Ericsson E, Hemlin C, et al. Paradigm shift in Sweden from tonsillectomy to tonsillotomy for children with upper airway obstructive symptoms due to tonsillar hypertrophy. Eur Arch Otorhinolaryngol. 2013; 270: 2531-2536.

[24] Zhang LY, Zhong L, David M, et al. Tonsillectomy or tonsillotomy? A systematic review for pediatric sleep-disorder breathing. Int J Pediatr Otolaryngol. 2017; 103: 41-50.

[25] Whelan RL, Schaffer A, Anderson ME, et al. Reducing rates of operative intervention for pediatric post tonsillectomy hemorrhage. Laryngoscope 2018; 128: 1958-1962.

[26] Arora R, Saraiya S, Niu X, et al. Post tonsillectomy hemorrhage: who needs intervetion? Int J Pediatr Otorhinolaryngol. 2015; 79: 165-169.

[27] Alm F, Jaensson M, Lundenberg S, et al. Adherence to Swedish guidelines for pain treatment in relation to pediatric tonsil surgery: a survey of the multidisciplinary team. Int J Pediatr Otorhinolaryngol. 2017; 101: 123-131.

[28] Bannister M, Thompson C. Post tonsillectomy dietary advice and haemorrhage risk: systemic review. Int J Pediatr Otorhinolaryngol. 2017; 103: 29-31.

[29] Hultcrantz E, Linder A, Markstörm A. Long-term effects of intracapsular partial tonsillectomy (tonsillotomy) compared with full tonsillectomy. Int J Pediatr Otorhinolaryngol. 2005; 69: 463-469.

(Erdélyi Eszter dr., Szeged, Tisza Lajos krt. 111., 6725 e-mail: eszter.erdelyil23@gmail.com)

A cikk a Creative Commons Attribution 4.0 International License (https://creativecommons.org/licenses/by/4.0/) feltételei szerint publikált Open Access közlemény, melynek szellemében a cikk bármilyen médiumban szabadon felhasználható, megosztható és újraközölhető, feltéve, hogy az eredeti szerző és a közlés helye, illetve a CC License linkje és az esetlegesen végrehajtott módosítások feltüntetésre kerülnek. (SID_1) 